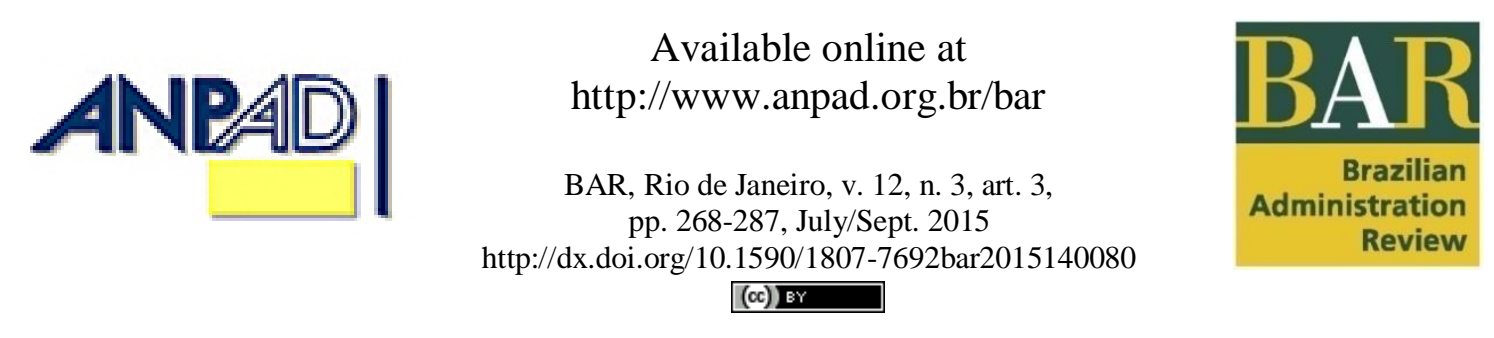

\title{
Leaderships in Urban Contexts of Diversity and Innovation: The Porto Maravilha Case
}

Fatima Bayma de Oliveira Fundação Getulio Vargas - FGV

Anderson de Souza Sant'Anna Fundação Dom Cabral - FDC

Daniela Martins Diniz Fundação Dom Cabral - FDC

Antonio Moreira de Carvalho Neto PUC Minas/PPGA

Received 27 November 2014; received in revised form 27 July 2015 (this paper has been with the author for two revisions); accepted $1^{\text {st }}$ September 2015; published online 30 September 2015. Editor's note. Ana Silvia Rocha Ipiranga served as Action Editor for this article. 


\begin{abstract}
This article investigates the role and ways of action of leaderships in urban contexts characterized by urban revitalization processes (RJ/Brazil). Adopting as its theoretical basis the bibliographical review of the literature on leadership and public area requalification processes, as well as research conducted by Jacobs (2011) on diversity and innovation, the present research may be characterized as qualitative in nature (case study). Results indicate that the Porto Maravilha project has transposed business concepts to public administration. Today, the keynote lies in the attraction of new enterprises and in the construction of urban revitalization projects for the city's makeover. With regard to the leadership, although public leadership has apparently adopted management instruments for decentralizing management and for public participation, these measures were not enough to achieve an effectively shared leadership that would reflect the multiple interests of different actors (as the theory of relational leadership presupposes). Thus, a set of contradictions and dilemmas for the leaders is apparent, among them: how to build an effectively-shared leadership, as every urban transformation project depends on the negotiation and complex interaction between different social actors?
\end{abstract}

Key words: shared leadership; local powers; urban revitalization; innovation in cities. 


\section{Introduction}

The role and relevance of cities in economic, institutional and social organization have been widely recognized in recent decades because of their centrality with regard to population's everyday life - a space that encompasses basic trades and services, an arena of social interaction, job generation, and many more purposes. Furthermore, various contemporary studies have shown their important role in attracting investments and as a stage for major urban interventions, which not only have the physical infrastructure but also local social structures. Therefore, it is worth reinforcing the importance of studies that contribute to a clearer understanding of such implications (Castells \& Borja, 1996; Ferreira, 2007; Monte-Mór, 2005).

Soja's study (2009) suggests that at present we can attain balance between the social, historical and spatial perspectives. Space starts to be seen as something dynamic and complex, full of action, contradictions and social processes, and not as a fixed component, without significant impact on social relationships, as it has been traditionally viewed.

Castells and Borja (1996) argue that the city as a protagonist must be regarded as a complex multidimensional social player, since it is the key locus of articulation between the different jurisdictions of public authority, civil society and the private sector.

In Latin America - unlike in European and North American countries - cities only gained prominence in the 1990s, boosted by political democratization processes. The consolidation at this level depends, for example, on development of major local projects containing local and private stakeholders, with the effective participation of public agents. Therefore, the investigation of this contemporary phenomenon could contribute to a clearer understanding of the leadership role in the context of protagonist cities.

In this logic of attracting urban change projects, the city becomes a merchandise/product that needs to develop differentials that ensure a competitive edge over other public spaces. In this context of interurban rivalry, the quality/location of space now becomes decisive in attracting investments (Araújo, 2011).

Castells and Borja (1996) raise the concept of market cities, which are now looked to as answers for five objectives: new economic base, urban infrastructure, quality of life, social integration and governability. One of the main approaches to making a city competitive and protagonist is to adopt the typical management model of private enterprise. This urban entrepreneurialism consists of a shift to reviewing the ways local governments do business, seeking to develop competitive edges and greater efficiency in urban management (Araújo, 2011; Compass, 2004; Harvey, 1989; Luchiari, 2005)

In the framework of professional urban management, the role of cities' political, community, business leaderships and their relations with other social players is questioned. After all, strategic city planning - commonly associated with the notion of entrepreneurial city (Borja \& Castells, 1997; Hall, 1995; Harvey, 1989; Kavaratzis, 2007; Vainer, 2000) - eventually weakens urban planning as a sole enterprise of the State, reinforcing perspectives of market rationality and style of leadership clinging more to business enterprises (Luchiari, 2005; Martinez, 2012).

In this sense, two implications are important in terms of leadership: one refers to the appropriation by public leaders of discourses and management practices typical of the corporate world - that can overcome the shortcomings from over-centralization and formality; and the other concerning a need to decentralize the power and decisions relating to urban planning with other players, whether private companies, civil society and so on. Thus, the search is to exercise a shared leadership, which is challenging given the diversity of the stakeholders' interests (Fischer, 1996).

So how are different social practices adopted when furthering sustainable organizational and territorial development? Development is built on inter-institutional, inter-organizational and 
interpersonal relations, reflecting multiple interests of the stakeholders operating in the global, local and organizational spheres. The universe of analysis is comprehensive and abstract, and may reconcile several power scales (Fischer, 1996).

With this context as a benchmark, this study aimed to analyze leaders and different social players' roles and ways of doing business in the urban context characterized by a process of cultural, socioeconomic and urban revitalization. To do so, it was opportune to: (a) describe the public space (Porto Maravilha, Rio de Janeiro, Brazil), considering the conditions of diversity and innovation (Jacobs, 2011) and the cultural and socioeconomic dynamics of the region studied; and (b) investigate the role and influence of emerging leaders and players in the context in question.

In methodological terms, a qualitative study was set up, using in-depth interviews (a total of twenty-one) and documentary analysis as collection tools. The selected case was the Harbor Area of the city of Rio de Janeiro, which has been undergoing extensive cultural, socioeconomic and urban revitalization since 2011. Not only is it one of the largest intervention projects ever in the city, but is also an extremely important cultural and historic region that has been in decline for decades.

One aspect stands out in terms of theoretical contributions to this study: the widening of discussions on leadership considering factors that go beyond organizational borders, providing evidence of inter-relationships between distinct, spatially-located social agents. In other words, it seeks to contribute with analyses that take into consideration the influence of space on the phenomenon of leadership, going beyond being a mere repository of social relationships. To recognize leadership as a contextual construct that emerges out of the complex interaction of leaders, social players, situations and organizational-urban environments is an important advancement for studies in the field, as it is a wider, multi-dimensional and dynamic perspective of the phenomenon of leadership. (Day \& O'Connor, 2003; Uhl-Bien, 2003).

In addition, the study expands reflections that have been undertaken in modern times on the role of leaderships at various levels - business, public and community -in the building of urban environments more in tune with diversity and innovation. To this end it contributes to widening the view of leadership, with a proposal to understand it as having a more systemic and relational character, involving the dimensions of society, of the organization and of the individual, simultaneously. Such an approach aligns with the more contemporary leadership models that develop the emphasis on individual leaders and propose the notion of shared leadership, which arises out of the networks of interaction between social players in complex environments. It therefore requires a view of leadership as something that pertains to the collective and that resides in a system (Day \& Harrison, 2007).

One should stress, in addition to what has already been mentioned, the important dialogue established between organizational and urban studies, such as the perspectives raised by authors like Jacobs (2011). Finally, at a practical level, contributions to the development of managerial policies and practices directed towards the building of urban-and also organizational - contexts more favorable to diversity and innovation are significant, as well as the manners of developing the proper leaderships to conduct them.

In addition to this introduction, the article addresses the theoretical review of the topic under analysis, the methodology used in the empirical study, and the empirical data analysis and conclusions of the study. 


\section{Theoretical Benchmark}

\section{Macro context: the notion of entrepreneurial city}

The failure of the so-called Virtuous Circle of Fordism (Lipietz, 1985), in the 1970s, directs companies and also cities to processes of restructuring, involving built-in strategies such as intensifying the search for new markets, introducing new technologies and more flexible workforce management models, as well as expanding the communication and transportation systems and substituting the rigidity of the Fordist model for a new flexible order of accumulation (Harvey, 1989).

In the city framework, such a movement is evidence of the spread of a discourse that emphasizes the modernizing role of global cities (Ferreira, 2007; Kavaratzis, 2007; Martinez, 2012). A model that is structured on the idea that it is up to cities to be ready for the new global economy forces, acting as a physical support for the economic flows and corporate business.

From this perspective, some studies have specialized in discussing this new modality of strategic planning and urban marketing in the city context - broadly modeled on business management theories (Ferreira, 2007; Harvey, 1989). This plan presupposes the city as a magnet for business or capital, looking to make it competitive by investments in extensive local restructuring, communication and promotion (Harvey, 1989; Vainer, 2000).

For decades, many cities have adopted a philosophy of marketing and have applied techniques to reach their strategic and operational objectives (Kavaratzis, 2007; Martinez, 2012). According to Kavaratzis (2007), the commercialization of the city has constituted an important field of scientific investigation. Large European and North American cities, following this prescription, have undertaken large-scale operations of urban revitalization in degraded areas (Ferreira, 2007).

This contemporary trend of city planning may well weaken urban planning as a role exclusive to the State, reinforcing prospects of strategic planning conducted in partnership with private business (Luchiari, 2005). This new management phase of the city could be understood as urban entrepreneurialism, in which the public administrator is being mistaken for the private investor (Hall, 1995).

The transformation of the entrepreneurial city, however, means adopting a participative management model not centered on the figure of the public administrator. It therefore needs consensus between local leaders in order to legitimize the city's vocation. Accordingly, arguments from the leftwing urban movements are common: grassroots participation, importance of local authorities, and responsible role of civil society (Ferreira, 2007).

There are, in this direction, some decisive elements for urban local responsiveness: (a) the presence of interacting leaders that can make changes; (b) an active and transparent municipal government; and (c) a view of the city focusing on the integration of the urban fabric with the different forms of social action (Castells, 1999). In relation to this last element, Soja (2009) suggests that the urban space should be viewed as something dynamic and complex, full of action, contradictions and social processes and not as a fixed component, without significant impact on social relationships.

Although aware of the variables that influence the transformation process of the entrepreneurial city, some projects have not been effectively consolidated due to the interference of interests of social groups not previously considered, and/or insufficient institutional conditions (financial resources, technical capacity and appropriate legal framework), as suggested by Compans (2004).

Furthermore, the study by Saldanha (2007) investigates the implications about the morphology of cities resulting from the invasion of new visitors and dwellers caused by revitalization projects of urban regions. Among the effects of this process, the author stresses the following: real estate speculation, 
space exploitation for immediate profit, which has transformed many cities into real open-air markets, and loss of city unity, especially in its fabric and landscape.

In order to minimize such impacts, Saldanha (2007) suggests adopting strategies to help raise the population's awareness about the importance of the region's cultural and natural heritage and, first and foremost, encourage the people to participate, since it is impossible to undertake interventions without the city inhabitants' collaboration. In addition, it is important to develop and train local leaders, whose practices are based on the notion of sustainability, and also the ability to encourage actions suited to the region's vocation and the demands of the moment.

Fischer (1996) believes that, without leadership, it would be hard to raise a reaction to such challenges. In fact, the leadership phenomenon permeates city life, from its administration, representation of authority, mastering the symbolic, and influencing the collective and individual.

\section{The street as a metaphor for flexibility, diversity and innovation}

In order to understand the dynamics of cities, one admits as fundamental the combinations and mixtures of the use of space and the diversity generated by the different tastes, skills and needs of people who, somehow, relate to the place (Jacobs, 2011). Analyzing streets in terms of flexibility, diversity and innovation has helped verify, in the case of this study, whether the rehabilitation project of the urban spaced investigated has contributed to the streets acquiring such valuable characteristics.

Jacobs (2011) investigated situations that generate diversity in urban dynamics and where economic reasons enable its generation. As a result, the author has acknowledged the existence of four conditions necessary for creating an exuberant diversity in the streets and neighborhoods. The first condition highlights the fact that the streets must fulfill more than one main function and guarantee the presence of people who leave their houses at different times and for different reasons, and that they can use substantial parts of the local infrastructure (Jacobs, 2011).

From this perspective, people must frequent the streets at different times in order to ensure proper circulation during the day and night. The presence of people, besides ensuring safety in the streets, contributes to enliven local business. These different combinations of uses for cities are not, therefore, a form of chaos; on the contrary, they are a complex and well-developed form of organization, which enables cities to create diversity and endure.

The second condition is related to the size of the blocks, which means that, according to Jacobs (2011), most city blocks must be short and streets and opportunities to turn corners must be frequent. Isolated neighborhoods risk being forgotten.

The third condition proposed by Jacobs (2011) concerns both the aesthetics and characteristics of the buildings. According to the author, streets must mingle buildings varying in age and condition, including a good proportion of old buildings. An area that has only new buildings tends to restrict the establishment of smaller businesses, which cannot pay the costs of new construction. On the other hand, local bars and typical restaurants, for instance, occupy old buildings and contribute to diversity.

The flow of people and the intended use of the public space are the fourth condition proposed by Jacobs (2011). According to the author, there must be a sufficiently dense concentration of people, for whatever their purposes may be, including individuals who live in the area. It must also include a considerable flow of strangers who pass by or work in the area.

Thus, if an area is to show exuberant diversity - the ability to gather different tastes, skills and needs - it must necessarily show a high density of people circulating, day and night, a mingle of new and old buildings that are able to accommodate different services, as well as small blocks that could ease the circulation and the encounter of people. 
The same author (2011) also discusses mistaken interpretations of the role of diversity. The idea that a mixture of different uses is aesthetically ugly, congests streets and encourages perverse uses of cities reflects the low diversity of spaces. The author demystifies beliefs that diversity is related to decadence and that places marked by homogeneity of use have better appearances and are more efficient. Homogeneity of use may seem to have some order at first, but this uniformity leads to monotony and prevents streets from being busy with the circulation of services and people. The appreciation for urban diversity, together with respect for freedom, is the fundamental aesthetic question for cities.

Regions showing vast potential for generating diversity and showing multiple economic and social uses may aspire, when properly articulated, to the kind of vitality that, in the opinion of Jacobs (2011), is capable of keeping cities on the move. Likewise, they point to the relevance of the role of leadership in the interaction of multiple elements capable of fostering this vitality, creating conditions for diversity and innovation and often propagating them in new contexts (Jacobs, 2011).

\section{Articulating multiple contexts: movement around leadership}

In a recent literature review on the topic, Sant'Anna, Campos and Lófti (2012) report that the attempt to understand leadership is a centuries-old human endeavor. Bass and Avolio (1990) attribute the first written record on the subject to the Egyptians in 2300 B.C., which indicates that leadership derives from something transcendental to human beings and designates superior qualities. In a more pragmatic attempt to understand the phenomenon, Maquiavel in The Prince (1972) describes types of government and how a leader should behave towards friends, and also procedures on how to stay in power.

In the $19^{\text {th }}$ century, however, studies focused more systematically on identifying characteristics of major figures that should act as a model for training new leaders. Such studies eventually culminated in the approach called Trait Theory, which concentrates on building lists of general personality traits that, when developed, would increase leadership potential (Seters \& Field, 1990).

A second important perspective of leadership studies is the behavioral approach, focusing on understanding the dynamics of leaders' behavior by studying individuals in leadership positions. The premise is that after learning about effective leadership behaviors, people could be trained to express such attitudes (Bergamini, 1994; Horner, 1997).

Extending this perspective, studies by Fiedler (1967) point to the contingent nature of leadership, where not only the leader but the led and the context are variables determining the leadership process. Thus the question is how to identify the most effective style for any given situation, instead of the best general style of leading.

Next, Burns (1978), based on studies of political leaders, offers new insight into the field of leadership, when he emphasizes sensitivity to people as a key aspect. The author puts forward a theory that includes two types of leaders: transformational and transactional. Leadership does not refer to the action of one person over another but to a process of two-way influence between leader and follower. Transactional leadership is found in an exchange between leader and followers, with rewards for the followers when better performing their tasks. The exchange can be economic, political or psychological, but without a lasting relationship between the parties.

Transformational leadership, on the other hand, goes beyond exchanging incentives and presumes self-development and intellectual stimulus of the followers so that they transcend individual interests in favor of collective goals. The motivational processes are based on an appeal to moral values going beyond individual interests. Bass and Avolio (1990) conducted studies that indicated more effectiveness of transformational over transactional leadership.

In the sphere of $21^{\text {st }}$-century organizations, study of the leadership process indicates diversity and quantity of variables to which the figure of the leader submits. Yammarino, Dansereau and Kennedy (2001) propose an approach that comprises different levels and dimensions of analysis (individual, 
leader-led, group and collective). The model also incorporates the following dimensions: Fundamental Human Process, Leadership Core Process, Leadership Outcomes, Other Multi-Level Outcomes and Substitutes for Leadership. The latter considers elements that could substitute for leadership as a factor of intervention to achieve the organizational goals (e.g.: informal relations; working groups that share responsibilities).

Reflecting on the leadership variables systemized by Yammarino et al. (2001) helps determine that the development of leadership requires an ongoing effort of self-knowledge, knowledge of others, internal environment and surrounding society. In the entrepreneurial city logic, it is essential that the leaders - political, community and business - understand the diversity of variables that they will have to address, as well as the different group and organizational relations that shall be built so that an urban transformation is conducted with sustainability.

A contemporary approach of the leadership literature that considers this connection between the dimensions of the individual, the organization, and society is the relational approach (Uhl-Bien, 2003, 2006). Such a perspective represents a more universal and systemic proposal in the field of leadership, seeking to go beyond traditional approaches that limit the analysis to the scope of the individual - group and/or of the organization. Relational theory assumes that leadership occurs in different spheres (in addition to the unidirectional relationships between leader/follower), embracing organizational, social and environmental aspects, as well as formal and informal leaders (Day \& Harrison, 2007; Uhl-Bien, 2006).

The objective of the Relational Leadership Theory is to improve the understanding of the relational dynamics and complex interactions that embrace leadership, the organization and society. According to Uhl-Bien (2006), the central problem that guides such research would be: what are the (social) relational processes through which leadership emerges and operates?

One of the great heralds of this approach is Uhl-Bien $(2003,2006)$, who considers relational leadership as a process of social influence, through which the social order and behaviors are constantly constructed and reproduced. Leadership, therefore, is a human social construct that emanates from the rich connections between its members, the organizations and their contexts. Such a perspective of relational leadership aligns with the style of leadership necessary in urban spaces going through a process of urban, socioeconomic and political transformation. In these environments, the exercise of a shared leadership, emerging from social interactions between the different agents, is a critical step for the region to make a quality leap in the direction of competitiveness (Fischer, 1996).

In relation to political leadership - one of the important aspects with regard to urban rehabilitation projects - the spread of the notion of entrepreneurial city has strengthened a new trait of public administration: the adoption of typical management concepts and practices from the corporate world, as already mentioned above. As a corollary, creativity, entrepreneurial approach, innovation, management decentralization, public-private partnerships are some of the terms that, gradually, join the vocabulary of public administration jurisdictions, Brazilian included (Pablo, Reay, Dewald, \& Casebeer, 2007). Consequently, the demand for reforms in the sector is now an important element of the national political agenda, being systematically inserted in the rhetoric of leaders and public administrators that should increasingly assume an entrepreneurial and managerial profile (Saraiva, 2002).

In the 1990s, this debate spread, the movement making inroads into a new public administration, which will accelerate the break up of archaic traits of the sector, based on traditionalism, personalism (Motta, 2007) and patrimonialism (Bresser-Pereira, 1996). More recently, new incursions are recorded towards modernizing the State, centered on public administration models that emphasize the notion of result and the adoption of typical managerial tools of scientific management, disseminated by large private organizations. Some projects of urban intervention developed in Brazil in recent years are already adopting traits of this management model of public administration (Bresser-Pereira, 1996). 


\section{Methodological Procedures}

Considering the traditional typology of research methods, the investigation carried out in the Harbor Area could be described as a qualitative field study, developed as a case study. Qualitative strategies are better suited to in-depth analysis of complex phenomena such as the extensive urban intervention named the Porto Maravilha Project (Yin, 2005). In addition, qualitative studies create possibilities for understanding meanings, from the perspective of the subjects, and of the situational characteristics presented by the interviewees, contributing to the perception of the phenomenon in a more systemic manner (Yin, 2005).

Bonoma (1985) says that descriptive studies relate to theories under construction and, accordingly, case studies fit the task best, because they provide a holistic understanding of the phenomenon. Case studies must reflect the context where actions take place and the temporal dimension in which facts occur. Their quality requires accurate perception of what is under analysis. The case is built taking as reference the researcher's interpretation of the phenomenon, rather than the objective reality (Yin, 2005).

Another advantage in the adoption of qualitative studies is that their results are essentially descriptive, as what one seeks is the exhaustive understanding of the phenomenon as a whole. It is therefore the appropriate research strategy when there are aspects to be elucidated in the existing theory or even when the variables are greatly intertwined (Godoy, 1995; Yin, 1981).

In view of what has been set out, qualitative research proved itself to be the most adequate strategy for analyzing the phenomenon investigated for various reasons, among them, because it: (a) appreciates the perspective of the different subjects participating in the research; (b) makes possible the comprehension of the complex relations and connections established between the agents; (c) favors the detailed understanding of the urban context in which the social players articulate (a crucial element for elucidating the research problem); and (d) finally, there are several aspects to be elucidated in the existing literature (Godoy, 1995; Yin, 1981).

In such studies, choosing the case is a crucial decision, because it has direct implications to the relevance of its outcome. The choice, therefore, should be intentional rather than random, and guided by the wealth of the phenomenon (Eisenhardt, 1989; Yin, 2005). Based on this premise, a decision was made to carry out an empirical study of the Harbor Area of the city of Rio de Janeiro, which, since 2011, has been undergoing a widespread revitalization process. Besides being one of the largest intervention projects implemented in Rio de Janeiro, the area, which has for decades been forgotten by the rest of the city, has great historical importance. The discovery of this region not only represents a possibility of growth for the city of Rio, but also the rediscovery of the rich artistic and cultural identity of the Harbor Area. Finally, the Harbor Area as the subject of our research was chosen based on expectations that the area will gradually develop more and more traits of diversity of uses and potential to generate innovations.

With regard to the data collecting tools, the study adopted in-depth interviews and analyses of documents, such as reports, scientific articles and urban and management projects (Eisenhardt, 1989; Soy, 1997; Yin, 2005). In the interviewee selection process the criterion of diversity was adopted in order to consider at least one representative of each group involved in the project, including entrepreneurs in the region before and after the start of revitalization; representatives of public organizations and the company responsible for coordinating the project (Companhia de Desenvolvimento Urbano da Região do Porto do Rio de Janeiro [CDURP]); presidents of neighborhood associations; old and new dwellers in the Harbor Area; and artists and school teachers in the region. Accordingly, it was possible to capture the perception of the different stakeholders, without focusing on any perspective linked to the revitalization project.

Twenty-one interviews were considered between February and August 2014, starting with the president of CDURP, who in turn, indicated business people in the region who facilitated access to the 
dwellers and so on. Therefore, the interview negotiation process was greatly facilitated by these recommendations and the fact that the majority of stakeholders were interested in having the project disseminated and discussed in the academic world (Table 1).

Table 1

\section{List of Interviewees}

\begin{tabular}{ll}
\multicolumn{1}{c}{ Interviewees } & Number \\
\hline President of CDURP & 1 \\
\hline Supervisor of Economic and Social Development of CDURP & 1 \\
\hline The project's financing institution & 1 \\
\hline Owners of companies established in the region & 5 \\
\hline Artists & 3 \\
\hline Workers in the region & 3 \\
\hline Residents & 2 \\
\hline President of Residents Association & 1 \\
\hline Professors of the school established in the region & 4 \\
\hline \multicolumn{1}{c}{ Total } & $\mathbf{2 1}$ \\
\hline
\end{tabular}

Note. Source: Prepared by the authors.

The interview script included different survey questions: (a) causes and implications of rehabilitation; (b) the main stakeholders in these dynamics, and the procedures and level of integration between them; (c) characteristics of the region from the aesthetic viewpoint, including the attending public, profile of projects and flow of people; and, lastly; (d) the challenges for the region's socioeconomic development and the lessons that this experience might provide.

The content analysis method by category was used for data treatment (Richardson, 1985). This methodology consists of using techniques of systemization and interpretation of the content of the collected data, in order to understand the discourse, develop its characteristics and extract the most important details. Hence, it was possible to examine several dimensions of the interviewee statements and reach conclusions from them.

To facilitate this stage, analysis categories were created based on the literature and reviewed in the light of empirical evidence (Eisenhardt, 1989; Godoy, 1995). In these terms, the main categories investigated were: (a) causes and consequences of the project; (b) leaderships and stakeholders; (c) level of integration between these groups; (d) the region's role, aesthetic characteristics, user flow and profile; (e) cultural, economic and social dynamics; (f) challenges and lessons. Lastly, we should mention that data were organized and systemized using NVivo qualitative analysis software.

\section{Data Presentation and Analysis}

\section{Porto Maravilha project: urban revitalization of the RJ Harbor Area, Brazil}

The purpose of implementing the Porto Maravilha Project in the Harbor Area in downtown Rio de Janeiro (Brazil), which started in 2011, is to integrate this 1,235-acre region with the rest of the city, thus putting a stop to the degradation process of the last decades (CDURP, 2014). 
Created by Municipal Law n. 101 (2009), this urban operation intends to encourage local restructuring, rehabilitation of public spaces and the socioeconomic development of the Harbor Area, in an attempt to offer better quality of life to residents, workers and entrepreneurs. The project includes the revitalization of the whole urban infrastructure, as well as improvements to the region's water, sewage, street lighting and communications systems, reshaping the traffic and transportation systems, and conserving historical monuments, green belts and public squares. Furthermore, the project offers an important cultural dimension, since at least $3 \%$ of the resources will be invested in the area's tangible and intangible assets (CDURP, 2014).

The Harbor Area revitalization is an initiative of Rio de Janeiro City Hall, supported by both state and federal administrations, although the resources to fund the works do not come from the city's budget. A new funding scheme was designed in which bonds - (Certificados de Potencial Adicional Construtivo [CEPACs]) - will be sold and purchasers will be able to exploit the area's constructive potential; in other words, they will be allowed to construct buildings and other structures beyond the current regulatory limits (CDURP, 2014).

Thus, the CEPAC scheme proved to be an important fundraising alternative for the works. The instrument, regulated by Federal Law n. 10.257 (2001), encourages the financing of large-scale construction works in Brazilian cities without tapping into municipal budgets.

The management of the Porto Maravilha project will be provided by the specially created CDURP, a partly private, partly state-owned company, independent from the city administration. CDURP will manage the distribution of job sites, financial and other resources associated with the project, as well as the interaction between public and private stakeholders. Construction work will be carried out by the contractor Concessionária Porto Novo, a company whose equity interest is shared by three construction firms. The timetable published on the CDURP website indicates that construction will be completed by 2016 .

\section{Macro context: the rehabilitation process of the Harbor Area}

The first point of investigation of the empirical study were the main aspects relating to the revitalization dynamics of the Harbor Area, representing the context that includes different agents and influences the locally established relations. It is apparent that the idea of revitalizing the Rio de Janeiro Harbor Area is not a recent one, and has already been the subject of discussion of past municipal governments. In other words, for decades there has been interest in making the Harbor Area an attraction with potential to be a center of private investment, as in the movement of entrepreneurial cities (Araújo, 2011; Kavaratzis, 2007; Martinez, 2012). However, the earlier projects had always come up against the question of funding, that is, "who was going to pay the bill" (Interviewee Statement 14).

Data reveal that the factor that has made it possible to carry out the project was the financing model conceived to relieve the public budget and fund the cost of the works from the sale of CEPAC bonds (Interviewee Statements 3, 10, 14, 16, 17, 21). It is a mechanism that has never been used before in interventions undertaken in the city of Rio and was groundbreaking in the sense that it enabled the implementation of a project idealized many decades earlier. It proved, therefore, to be an instrument along the lines of the idea of market cities that aspire to be innovative (Borja \& Castells, 1997; Luchiari, 2005). At the same time, it reinforces the argument of studies (Pablo et al., 2007) that indicate that the public leaders have looked to innovate based on models that were not traditionally adopted in public organizations.

"CEPACS are the means by which City Hall obtains the necessary funds to make the project happen. There isn't a financial structure to uphold this procurement of CEPACS at the speed in which it is being done, the value of what is being done and, at the end of the day, it is the sum of money that enables the project to be done" (Interviewee Statement 16).

In addition to the proposed model, another element was decisive in attracting interest for the Porto Maravilha project to leave the drawing board: the strategic importance of this central area for the city 
(Interviewee Statements 1, 2, 3, 10, 12). Considering the process of commercial and residential saturation of other Rio de Janeiro neighborhoods, the idea of rehabilitating a downtown area was promising. Not only does the restoration of the Harbor Area benefit the urban mobility of people and workers - a critical problem of capital cities -, but it also enables commercial and residential growth in a downtown part of the city. Thus, as Araújo (2011) suggests, in this context of interurban competition, the quality/location of the space is now decisive in attracting investments.

"Rio de Janeiro is geographically complex. You are between the sea and the mountains and there is very little land to be incorporated. The downtown area is empty. And this opportunity to have a new area, with new buildings, roads and infrastructure is paradise for the real estate market" (Interviewee Statement 2).

Concerning the opinion of the dwellers and workers in the Harbor Area in relation to the project, it is found that there is a clear division between those who are in favor of the intervention and those who regard the revitalization as an interest of outside groups (Interviewee Statements 13, 21). This finding might indicate that the leaders of the project have failed to attract some of the groups impacted by the transformation, in the sense of backing the implementation of the project, a situation that may jeopardize its legitimacy. Relational leadership - which presupposes leadership as a process of social influence arising out of the rich connections between individuals, organizations and their contexts - did not fully materialize in the project being analyzed (Uhl-Bien, 2003, 2006). Such a finding also reinforces Compans' (2004) statement that urban renewal can suffer from the interference of social groups that have not received prior consideration.

The group supporting the project alleges that the people want urban improvement in the region, but do not want to undergo the disruption caused by the works. They also indicate that the population was accustomed to a situation of neglect and, therefore, changes caused by the intervention upset the older residents (Interviewee Statements 3, 4, 7, 10). For example, the traditional storekeepers have felt an impact, since they will have to adapt their business to fit the new context.

"Since the area has been neglected for 50 years, the people here are used to ruin. Only those who are critical will be upset. So here the opinion was divided, many people say: nothing will change, the rich will come here, treat us like slaves and then leave. There is another group that says: hang on, let's wait and see what happens" (Interviewee Statement 10).

In terms of the factors favoring the revitalization process of the Harbor Area, it is worth mentioning the convergence of interests and alignment obtained between the local, state and federal governments (Interviewee Statements 1, 2, 10, 13, 16, 21). In the past, there was opposition between these jurisdictions of public authorities, making it hard to obtain the necessary support for implementing the project. Therefore, as Castells (1999) stresses, a group of interacting leaders (political, in this case) is a decisive factor in urban transformation projects.

On this matter, some interviewees called attention to the importance of City Hall leadership and the political desire to overcome obstacles to achieve such a grand urban intervention (Interviewee Statements 4, 17, 21). This finding reinforces the theoretical premise that local authority is essential in the framework of city revitalization (Ferreira, 2007; Fischer, 1996).

Another propitious factor mentioned in the empirical data was the creation of a company to address only the project (CDURP), an action in line with Fischer's argument (1996) that any change in the urban dimension requires local actions. The company is a facilitator, inasmuch as interfacing and arrangements are necessary between the different stakeholders in the project. Moreover, the project gives rise to a number of problems needing specific action by its facilitator (Interviewee Statements 1, 17).

This survey evidence also reinforces the theoretical notion that public administration has adopted tools typical of the corporate world. In this case, decentralizing the project's management and adopting the model of public-private partnership confirm this notion (Pablo et al., 2007; Saraiva, 2002). 
With regard to aspects that hinder the development of the project in the Harbor Area, it is worth mentioning the daily disruption that a job of this scale causes. Traffic, circulation and parking problems, streets closed, power and water cuts and noise are some of the local residents' complaints (Interviewee Statements 3, 4, 5, 17).

Another drawback emerging from the interviews is the population's skepticism about the project's implementation - since the plan has been discussed for decades - and the actual legacy that will stay with the region after completion of the works. In other words, in addition to the urban improvements, the population is claiming progress in areas that in its opinion are a higher priority (education, health, safety) (Interviewee Statement 1). Some dwellers understand, therefore, that when setting the priorities during the design of the project some demands of the local population have been ignored (Interviewee Statements 10, 13, 15, 19).

This empirical evidence reveals another angle of urban revitalization: the risk of urban entrepreneurship more attentive to interests of economic groups than to meet the needs of the local population. Araújo (2011) discusses the perverse effects of this process and reveals that, in many cases, citizen participation in the plan's design is questionable.

Among the contributions arising from the revitalization in progress in the Harbor Area, the opportunity for commercial growth and the anticipated residential expansion in the area were aspects emerging from the empirical data. An area is created to attract investments and open new business. Also expected after completing the project is an upgrade in the basic urban infrastructure, road and transportation system (Interviewee Statements 3, 4, 5, 10, 11, 17, 19). Such potential benefits indicate that the Harbor Area's transformation is based on some objectives inspired by the idea of an entrepreneurial city: finding a new regional economic base, improved urban infrastructure and quality of life, as postulated by Castells and Borja (1996).

Revitalizing the region's cultural heritage is also a positive consequence of the Porto Maravilha project. This transformation not only adds value to the historical equipment of the place, but also strengthens the local cultural vocation, and is an asset for the city of Rio de Janeiro as a whole. Consequently, self-esteem of the local population is visibly restored, creating a feeling of belonging, a key element for cities that aspire to be competitive. In other words, as pointed out by Fischer (1996), a community with low self-esteem is unable to project an effective image of its culture and potential.

"It creates conditions for the Harbor Area to now belong to the rest of the city. This integration will be very positive, especially for the residents' self-esteem. And for those living there, it is the reaffirmation of this identity 'I live in the Harbor Area and it's so cool'. And this creates a much stronger entrepreneurial spirit. It's a guarantee of sustainability for the tangible and intangible assets" (Interviewee 21).

If the project is beneficial for some issues, other negative impacts have also been felt, in addition to the aforementioned disruption of the works (Interviewee Statements 5, 7, 8, 15, 18, 19). One effect now having a negative bias is the real estate appreciation and consequent increase in the price of land and properties, confirming the study by Saldanha (2007). Revitalization has, in fact, given rise to an expropriation of people living in rented accommodation and businesses under lease agreements, since not all are able to absorb the soaring prices (Interviewee Statements 4, 6, 7, 12, 15, 20). Thus, cities could be transformed into open-air markets, benefiting hegemonic economic groups (Saldanha, 2007).

"Eighty-three percent (83\%) of businesses here are rented. This is a region with decades of a legacy of neglect, where the property owners would rent at very low prices. Now, they are being updated because of the transformation. And this will heavily impact the business margin" (Interviewee Statement 12). 


\section{Leaderships: stakeholders in the dynamics and level of integration}

Another important analysis category of the survey includes leaders and institutions that have been highlighted in the rehabilitation process of the Harbor Area. In the interviews, the mention of the figure of Mayor of the city of Rio de Janeiro has been recurring (Castells, 1999; Castells \& Borja, 1996), because it is a project that has been planned over many years and only now has succeeded in being implemented (Interviewee Statements 1, 2, 5, 12, 14, 16). Therefore, many interviewees attribute to the Mayor the courage, drive and dedication to the Harbor Area. Some characteristics of this leadership have been quoted in interviews: vision, pragmatism, entrepreneurialism, courage to take risks and determination to break down the inertia of public administration.

This evidence confirms at least two issues discussed in the theoretic review of this study: (a) the importance of local authorities in urban revitalization projects (Castells, 1999; Ferreira, 2007); and (b) the political leaders adopting management practices and arguments common in the business context (Saraiva, 2002).

"The Mayor of the City, because he really has extremely admirable vision and courage. All this traffic upheaval of having to close roads, all those obstacles in place show his admirable courage. He is challenging public opinion and a lot of resistance" (Interviewee Statement 2).

The companies that have been appointed for the executive management of the project (CDURP) and the winning contractor in the bid for implanting the works (Porto Novo) have also been remembered in the interviews (Interviewee Statements 5, 17, 18), evidencing the relevance of stakeholders that work locally (Fischer, 1996). This model of public-private partnership includes characteristics of more decentralized public project management (Luchiari, 2005). Although the population did not choose these companies directly, which may have caused a feeling of lack of community participation, they are political benchmarks that people consider in relation to the Porto Maravilha project.

With regard to the presence of leaders in the local population frame, opinions are divided. Some interviewees suggest that the representatives of the neighborhood associations are active locally and take the population's demands to the companies conducting the project (Interviewee Statements 1, 17, 21). In addition to these agents, arts groups have acquired a voice with the revitalization and, today, are able to influence some local issues of interest.

In contrast with this view, another group of interviewees understands that the scenario is lacking in local leaders (Interviewee Statements 12, 15, 18). Since this is an area that has been forgotten for decades, it did not offer a propitious context for raising active leaders, in line with the idea of Jacobs (2011) that only densely populated areas with different goals create conditions for innovation and entrepreneurialism.

In this vein, interviewees suggest that there is much less social interaction than desirable among the people from the Harbor Area, a situation that could somehow be detrimental to building up sustainable urban development, since this depends on the interaction of the stakeholders' multiple interests (Fischer, 1996). Also it is found that relations are distant between people from different neighborhoods, something deeply rooted in the region's historical process (Interviewee Statements 15, $18)$.

"I think that it could be, if people were to unite on these matters of citizenship. But people here are not yet ready for this, they're fine people, but quite complicated in terms of the collective" (Interviewee Statement 15).

The low articulation found between the social actors tends to jeopardize the exercise of a shared and relational leadership, as it emerges precisely at the relational connections established in a determined locality (Uhl-Bien, 2003, 2006). Such a situation can be one of the great barriers to the port region giving a quality leap in the direction of competitiveness (Fischer, 1996). 
With regard to interaction between the company responsible for the rehabilitation project (CDURP) and the population's representatives, it is noted that there is a channel of communication and dialogue between these stakeholders. There is evidence that CDURP listens to the population's demands, participates in forums, convenes the associations and interfaces where it considers necessary (Interviewee Statements 11, 14, 19, 21).

Concerning the leadership theme in the Harbor Area context, although public leaders have been seen to adopt management instruments (decentralization of administration, and so on), this action has not been enough to achieve a shared leadership that would reflect the multiple interests of the different actors. It is understood at the same time that the social connections established in the urban context analyzed were not sufficient for the building of a relational leadership capable of articulating multiple instances (individuals, organizations and society) (Uhl-Bien, 2003, 2006; Yammarino, Dansereau, \& Kennedy, 2001).

\section{Harbor area characteristics: aesthetic and business profile and local public}

In terms of the economic activities in the Harbor Area, this segment is slowly changing. Many interviewees have reported that there still is a shortage of commerce and basic utilities (Interviewee Statements 1, 3, 4, 7, 20). In the past, the region was marked by the presence of public institutions - still located in the area - and services/ commerce focusing on attending the port segment (Interviewee Statements 1, 3, 5).

Since the Porto Maravilha project covers quite an extensive geographic area, there is heterogeneity in terms of economic activities in the different neighborhoods (Interviewee Statements 4, 12). Nevertheless, there seems to be an increasing number of enterprises for gastronomy and entertainment (Interviewee Statements 1, 7, 11). According to SEBRAE data (Serviço de Apoio as Micro e Pequenas Empresas), restaurants are responsible for $17 \%$ of the business in the region and therefore relevant in local economic dynamics (Interviewee Statement 12). Other enterprises are fairly scattered with no concentration.

Moreover, with the revitalization of the historic heritage of the region and given the local cultural vocation, the arrival of new projects in the artistic and entertainment sector is expected (Interviewee Statements 1, 12). In other words, the more attractive the region in the eyes of the investors, the more possible it is to develop local economic dynamics (Ferreira, 2007). Also, this attraction of the Harbor Area tends to contribute to increase diversity in terms of services and commerce, which according to Jacobs (2011) is fundamental to expand the ways of using public space and to generate vitality.

In relation to the business profile, there is still a strong presence of small very traditional storekeepers, in that they have a more informal, less professional management model. With the arrival of a new public to the region, these small enterprises will have to adapt to a new more competitive and demanding environment.

From the aesthetic viewpoint, the harbor region is quite varied, covering an area of 1,235 acres. Nevertheless, it is possible to note a strong presence of some old and dilapidated buildings, the result of the process of neglect over the last few decades. Evidently some places have already been recovered with urban intervention.

In addition to restoring the traditional architecture of some buildings, the project has endeavored to attract new buildings with a more contemporary style. Therefore, the idea is to have a mix of old and new, contributing to an aesthetic diversity of the region (Jacobs, 2011). On this aspect, divided opinions are apparent. While some appreciate the mix of the old and new (Interviewee Statements 1, 16, 21), others stress that it is essential to keep the old aesthetics of the region (Interviewee Statement 3).

One of the points raised for the Porto Maravilha project is the concern that the region has a commercial and residential mix. Many interviewees attribute to this factor the success of the project, 
alleging that it must have movement and life at all times and a place where people come for different reasons, in line with the studies by Jacobs (2011).

"It cannot be a place only for business development, it has to be mixed housing. This mix is vital for the long-term success of the area. There are ' $n$ ' examples of revitalization projects implemented around the world, and those that got it right were those that chose a multi-development model. The modern idea of a city is that it has to be a living organism, with its eyes open day and night" (Interviewee Statement 16).

Formerly, the population in the region included the residents, workers of public agencies and small businesses. The inhabitants are mostly characterized as workers employed in other parts of the city and who return to the Harbor Area at the end of the day. Some of this population live in rented accommodation and are in a lower income bracket (Interviewee Statement 12). According to Interviewee 12 , its population came to live in the region precisely because it was a neglected area.

With the Porto Maravilha project in progress, the region has been (re)discovered by different publics, a key aspect to enable diversity of public space uses, according to Jacobs (2011). New groups can now be seen in the region because of the appreciation of the cultural elements, or to participate in some of its local events (Interviewee Statements 5, 10).

In terms of rush hour, the Harbor Area is seen to follow the flow of city downtowns: very busy during the day and much emptier at night and on weekends (Interviewee Statements 2, 4, 5, 17, 18, 20). Of course, some change in this situation has been noticeable with the emergence of evening events. However, little movement at night is still a concern. According to Jacobs (2011), this concentration reduces the safety of the place and a solution to increase the density of people would be to install residential buildings to increase the number of individuals circulating during the day and night.

\section{Challenges for developing the Harbor Area}

In relation to the challenges for sustainable development of the Harbor Area, the mix between residential and commercial is one of the major concerns. Survival of the region depends on the mix of uses and dynamics that such projects could generate for the area (Interviewee Statements 4, 16), a finding converging with Jacobs' study (2011).

Another challenge underscored in the interviews is the conclusion of the works in progress in the region, with consolidation of all improvements proposed in the project. Since this project has already been planned for many decades, there is a certain mistrust that all the work will not be completed, a common feeling towards present-day public administration.

A third challenge concerns the aspect of employability in the area, since the city is the locus of job generation, according to Castells and Borja (1996). In other words, some interviewees point out that there is no preference for local labor, and those who have occupied the jobs in the region are people from other neighborhoods (Interviewee Statement 11). On the other hand, some interviewees warn that vacancies are offered to local dwellers and apparently this public has shown no interest in the offers (Interviewee Statements 5, 12, 14).

On analyzing the lessons from the intervention regarding capacity building for diversity and innovation, the interviewees stress that experience points to the relevance of: (a) new forms of coexistence and balance between the old and the new, furthering different levels of diversity (Jacobs, 2011); (b) local leaders in the different jurisdictions (community, political, business) so that the project reflects multi-interests (Fischer, 1996); and (c) a decentralized model of administration, with the creation of a company solely to coordinate projects in the cities and use the public-private partnership to contribute to the implementation of the project (Pablo et al., 2007). 


\section{Final Considerations}

The idea of revitalizing a region in a city and making it an element of attraction and socioeconomic development, such as in the Rio de Janeiro Harbor Area, is a good example of urban planning inspired by business management theories, with more affinity to the demands of cities than seeking to be competitive. This project consists of a Brazilian case of rehabilitating a degraded area, as has occurred in different European and North American cities (Ferreira, 2007; Kavaratzis, 2007; Martinez, 2012).

In this vein, we noted that the rehabilitation of the Harbor Area has potential to help improve the attributes of diversity of uses, flexibility and mixes between the old and new; valuable characteristics for an urban area under reconstruction, as highlighted by Jacobs (2011).

The empirical data also reveal some decisive aspects for completion of the Porto Maravilha project: the adopted financing model; the strategic importance of the area for the city; the alignment between governments; and the creation of a company solely for developing the project. These factors are related to elements raised in the literature as relevant for an urban area to take a leap towards competitiveness: the relevance of local authorities (Fischer, 1996), an active municipal government and interacting with other public authority jurisdictions (Ferreira, 2007) and the adoption of management practices typical of the corporate world (Pablo et al., 2007).

Therefore, as has been possible to transpose business concepts to public administration in other Brazilian cities, this situation in the Porto Maravilha project is no exception. Today, the keynote lies in the attraction of new enterprises and in the construction of urban revitalization projects for the city's makeover. The result is a noticeable change in the role of the State, which gradually leaves the stage, no longer the main administrators of public space, opening the way for other private players as a major producer of new cityscapes (Luchiari, 2005).

With regard to the leadership topic in the context of the Harbor Area, although public leadership has apparently adopted management instruments for decentralizing management and for public participation, these measures were not enough to achieve an effectively shared leadership that would reflect the multiple interests of the stakeholders. Concomitantly it was found that the social connections established in the urban context analyzed were not sufficient to build a relational leadership capable of articulating multiple instances (individuals, organizations and society) (Uhl-Bien, 2003, 2006; Yammarino et al., 2001).

Consequently, some groups have revealed that their demands have not been met, putting in doubt the actual citizen participation in the plan's concept. This raises the following question: does urban revitalization run the risk of benefiting the interest of certain groups?

Such results take us back to the considerations made in the review of the literature of this article, specifically in relation to the importance of democratic participative and inclusive planning processes in urban contexts that contemplate the participation of different social players. At the same time, it calls our attention to the fact that the success of urban renewal depends, among other things, on the creation of shared leaderships, capable of stimulating social connections between the different groups affected by the process (Uhl-Bien, 2003, 2006). In this sense, the doubt remains whether such preconditions were in force in the Porto Maravilha project.

Thus, a set of contradictions and dilemmas for the leaders is apparent. How then is leadership effectively shared, since every urban transformation project is the result of negotiation and interaction between the public and private urban players? 


\section{References}

Araújo, F. F. de (2011, novembro). Empresariamento urbano: concepção, estratégias e críticas. Anais da Conferência do Desenvolvimento CODE, Brasília, DF, Brasil, 2. Retrieved from http://www.ipea.gov.br/code2011/chamada2011/pdf/area7/area7-artigo7.pdf

Bass, B. M., \& Avolio, B. J. (1990). The multifactor leadership manual. Palo Alto, CA: Consulting Psychologists Press.

Bergamini, C. W. (1994). Liderança: administração do sentido. São Paulo: Atlas.

Bonoma, T. V. (1985). Case-research in marketing: problems and opportunities and a process. Journal of Marketing Research, 22(2), 199-208. doi: 10.2307/3151365

Borja, J., \& Castells, M. (1997). Local y global, la gestión de las ciudades en la era de la información. Madrid: Santillana de Ediciones, S.A.

Bresser-Pereira, L. C. (1996). Da Administração pública burocrática à gerencial. Revista do Serviço Público, 120(1), 7-41. $\quad$ Retrieved from http://www.bresserpereira.org.br/papers/1996/95.AdmPublicaBurocraticaAGerencial.pdf

Burns, J. M. (1978). Leadership. New York: Harper \& Row.

Castells, M. (1999). A sociedade em rede. São Paulo: Paz e Terra.

Castells, M., \& Borja, J. (1996, julho). As cidades como atores políticos. Novos Estudos Cebrap, (45), $152-166$ Retrieved

from http://novosestudos.uol.com.br/v1/files/uploads/contents/79/20080626_as_cidades_como_atores.pdf

Companhia de Desenvolvimento Urbano da Região do Porto do Rio de Janeiro. (2014, April 4). $\begin{array}{llll}\text { Apresentação do projeto. } & \text { Retrieved }\end{array}$ http://www.portomaravilha.com.br/web/sup/OperUrbanaApresent.aspx

Compans, R. (2004). Intervenções de recuperação de zonas urbanas centrais: experiências nacionais e internacionais. In EMURB, Caminhos para o centro: estratégias para desenvolvimento da região central da São Paulo (pp. 24-57). São Paulo: PMSP/CEBRAP.

Day, D. V., \& Harrison, M. M. (2007). A multilevel, identity-based approach to leadership development. Human Resource Management Review, 17(4), 360-373. doi: 10.1016/j.hrmr.2007.08.007

Day, D. V., \& O'Connor, P. M. G. (2003). Leadership development: understanding the process. In S. E. Murphy \& R. E. Riggio (Eds.), The future of leadership development (pp. 11-28). New Jersey: Lawrence Erlbaum Associates Inc.

Eisenhardt, K. M. (1989). Building theories from case study research. Academy of Management Review, 14(4), 532-550. doi: 10.5465/AMR.1989.4308385

Ferreira, J. S. W. (2007). Globalização, ideologia e planejamento urbano. In J. S. W. Ferreira, $O$ mito da cidade-global: o papel da ideologia na produção do espaço urbano (pp. 117-125). Petrópolis: Vozes.

Fiedler, F. E. (1967). A theory of leadership effectiveness. New York: McGraw-Hill.

Fischer, T. (1996). Gestão contemporânea, cidades estratégicas: aprendendo com fragmentos e reconfigurações do local. In T. Fischer (Org.), Gestão contemporânea: cidades estratégicas e organizações locais (pp. 10-26). Rio de Janeiro: Editora da Fundação Getúlio Vargas. 
Godoy, A. S. (1995). Introdução à pesquisa qualitativa e suas possibilidades. Revista de Administração de Empresas, 35(2), 57-63. doi: 10.1590/S0034-75901995000200008

Hall, P. G. (1995). Cidades do amanhã: uma história intelectual do planejamento e do projeto urbanos do século XX. São Paulo: Perspectiva.

Harvey, D. (1989). Condição pós-moderna. São Paulo: Edições Loyola.

Horner, M. (1997). Leadership theory: past, present and future. Team Performance Management, 3(4), 270-287. doi: 10.1108/13527599710195402

Jacobs, J. (2011). Morte e vida de grandes cidades. São Paulo: WMF Martins Fontes.

Kavaratzis, M. (2007). City marketing: the past, the present and some unresolved issues. Geography Compass, 1(3), 695-712. doi: 10.1111/j.1749-8198.2007.00034.x

Lipietz, A. (1985). Miragens e milagres: problemas da industrialização no terceiro mundo. São Paulo: Nobel.

Luchiari, M. T. D. P. (2005, março). Centros históricos: mercantilização e territorialidades do patrimônio cultural urbano. Anais do Encontro de Geógrafos da América Latina, São Paulo, SP, Brasil, 10.

Maquiavel, N. (1972). O príncipe (2a ed., Trad. Roberto Grassi). Rio de Janeiro: Civilização Brasileira.

Martinez, N. M. (2012). City marketing and place branding: a critical review of practice and academic research. Journal of Town and City Management, 2(4), 369-394.

Monte-Mór, R. L. (2005). A questão urbana e o planejamento urbano-regional no Brasil contemporâneo. In C. C. Diniz \& M. B. Lemos (Eds.), Economia e território (pp. 429-446). Belo Horizonte: Editora UFMG.

Motta, P. R. (2007). A modernização da administração pública brasileira nos últimos 40 anos [Edição Especial]. Revista de Administração Pública, 41, 87-96. Retrieved from http://www.scielo.br/pdf/rap/v41nspe/a06v41sp.pdf. doi: 10.1590/S0034-76122007000700006

Pablo, A. L., Reay, T., Dewald, J. R., \& Casebeer, A. L. (2007). Identifying, enabling and managing dynamic capabilities in the public sector. Journal of Management Studies, 44(5), 687-708. doi: 10.1111/j.1467-6486.2006.00675.x

Richardson, R. (1985). Pesquisa social: métodos e técnicas. São Paulo: Atlas.

Saldanha, E. E. (2007). Modelo de avaliação de sustentabilidade socioambiental (Tese de doutorado). Universidade Federal de Santa Catarina, Florianópolis, SC, Brasil.

Sant'Anna, A. S., Campos, M. S., \& Lófti, S. (2012). Liderança: o que pensam executivos brasileiros sobre o tema? Revista de Administração Mackenzie, 13(6), 48-76. Retrieved from http://www.scielo.br/pdf/ram/v13n6/a04v13n6.pdf. doi: 10.1590/S1678-69712012000600004

Saraiva, L. A. S. (2002). Cultura organizacional em ambiente burocrático. Revista de Administração Contemporânea, 6(1), 187-207. Retrieved from http://www.scielo.br/pdf/rac/v6n1/v6n1a11.pdf. doi: $10.1590 /$ S1415-65552002000100011

Seters, D. A. V., \& Field, R. H. G. (1990). The evolution of leadership theory. Journal of Organizational Change Management, 3(3), 29-45. doi: 10.1108/09534819010142139

Soja, E. W. (2009). Regional planning and development theories. In N. Thrift \& R. Kitchin (Eds.), The international enciclopedia of human geography (pp. 259-270). Amsterdam: Elsevier. 
Soy, A. K. (1997). The case study as research method. Retrieved from https://www.ischool.utexas.edu/ ssoy/usesusers/1391d1b.htm

Uhl-Bien, M. (2003). Relationship development as a key ingredient for leadership development. In S. Murphy \& R. Riggio (Eds.), The future of leadership development (pp. 129-147). Mahwah, NJ: Lawrence Erlbaum Associates Inc.

Uhl-Bien, M. (2006). Relational leadership theory: exploring the social processes of leadership and organizing. The Leadership Quarterly, 17(6), 654-676. doi: 10.1016/j.leaqua.2006.10.007

Vainer, C. (2000). Os liberais também fazem planejamento urbano? In O. Arantes, C. Vainer, \& E. Maricato, A cidade do pensamento único: desmanchando consensos (pp. 105-119). Petrópolis: Vozes.

Yammarino, F. J., Dansereau, F., \& Kennedy, C. J. (2001). A multiple-level multidimensional approach to leadership: viewing leadership through an elephant's eye. Organizational Dynamics, 29(3), 143-163.

Yin, R. K. (1981). The case study crisis: some answers. Administrative Science Quartely, 26(1), 58-65.

Yin, R. K. (2005). Estudo de caso: planejamento e métodos. Porto Alegre: Bookman.

\section{Authors' Profiles}

Fatima Bayma de Oliveira

Praia de Botafogo, 190, 22250-900, Rio de Janeiro, RJ, Brazil. E-mail address: fbayma@fgv.br

Anderson de Souza Sant'Anna

Alphaville, Av. Princesa Diana Nova Lima, 760, 34000-000, Nova Lima, MG, Brazil. E-mail address: anderson@fdc.org.br

Daniela Martins Diniz

Alphaville, Av. Princesa Diana Nova Lima, 760, 34000-000, Nova Lima, MG, Brazil. E-mail address: danidiniz09@yahoo.com.br

Antonio Moreira de Carvalho Neto

Av. Itaú, 525, Bairro Dom Cabral, 30535-012, Belo Horizonte, MG, Brazil. E-mail address: ppga@ pucminas.br 